\title{
Bone marrow transplant model to study articular cartilage repair
}

\author{
Ana Sergijenko*, Anke J. Roelofs, Andrea Augello, Cosimo De Bari \\ From 1st Annual Meeting of the Scottish Society of Cytomics (SCC) 2014. "Translational Cytometry from \\ Bench to Bedside" \\ Aberdeen, UK. 25 September 2014
}

We have previously established a mouse model of spontaneous cartilage repair following a full thickness injury and are studying the contribution of mesenchymal stem cells (MSCs) to this process. To determine the contribution of MSCs from bone marrow, we developed a chimeric model by transplanting eGFP+ bone marrow cells into lethally myeloablated wild-type mice. Stromal cell chimerism was confirmed in bone marrow by flow cytometry based on the CD45-/Sca1+/Pdgfr- $\alpha+/$ GFP+ selection and CFU-F assay. GFP+ cells were first detected in synovium at 7 days post-transplant (5\%), which increased to $40 \%$ of nucleated cells at 8 weeks. GFP+ cells in the synovium were positive for stromal cell markers CD44 and cadherin11, but not endothelial cell markers. To further validate this model, we assessed the response of donor cells to cartilage injury in the synovium post-transplant. Chimeric mice underwent joint surface injury and immediately received a nucleoside analogue chlorodeoxyuridine (CldU) in water for 7 days, after which mice were analysed. There was an increase of donor-derived GFP+ cells in synovium of injured mice compared to uninjured, however, the number of proliferating cells (GFP+/ CldU+) did not increase significantly, suggesting that bone marrow derived cells do not proliferate in situ, but rather infiltrate from bone marrow. In conclusion, we established a chimeric mouse model that will allow us to track contribution of bone marrow cells to cartilage repair.

Published: 16 April 2015
doi:10.1186/1476-9255-12-S1-P9

Cite this article as: Sergijenko et al: Bone marrow transplant model to study articular cartilage repair. Journal of Inflammation 2015 12(Suppl 1): P9.

* Correspondence: a.sergijenko@abdn.ac.uk

Regenerative Medicine Group, Musculoskeletal Research Programme, University of Aberdeen, Scotland, AB25 2ZD, UK

Submit your next manuscript to BioMed Central and take full advantage of:

- Convenient online submission

- Thorough peer review

- No space constraints or color figure charges

- Immediate publication on acceptance

- Inclusion in PubMed, CAS, Scopus and Google Scholar

- Research which is freely available for redistribution

Submit your manuscript at www.biomedcentral.com/submit
() Biomed Central

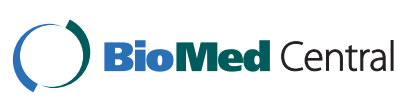

(c) 2015 Sergijenko et al; licensee BioMed Central Ltd. This is an Open Access article distributed under the terms of the Creative Commons Attribution License (http://creativecommons.org/licenses/by/4.0), which permits unrestricted use, distribution, and reproduction in any medium, provided the original work is properly cited. The Creative Commons Public Domain Dedication waiver (http://creativecommons.org/publicdomain/zero/1.0/) applies to the data made available in this article, unless otherwise stated. 